\title{
LA CEGUERA A LOS COLORES DE PAUL MANSHIP (1885-1966)
}

\author{
MIR-FULLANA F ${ }^{1}$
}

Paul Manship nació en Saint Paul en Minnesota y desde muy pequeño tuvo facilidad para el dibujo. Durante su adolescencia recibió clases de pintura en la escuela de arte de aquella ciudad con la firme determinación de llegar a ser un buen pintor. Pero en aquella época juvenil le fue diagnosticada una ceguera a los colores.

Como muchos otros artistas con este tipo de deficiencias, Manship abandonó todos sus proyectos pictóricos trasladando su dedicación a la escultura.

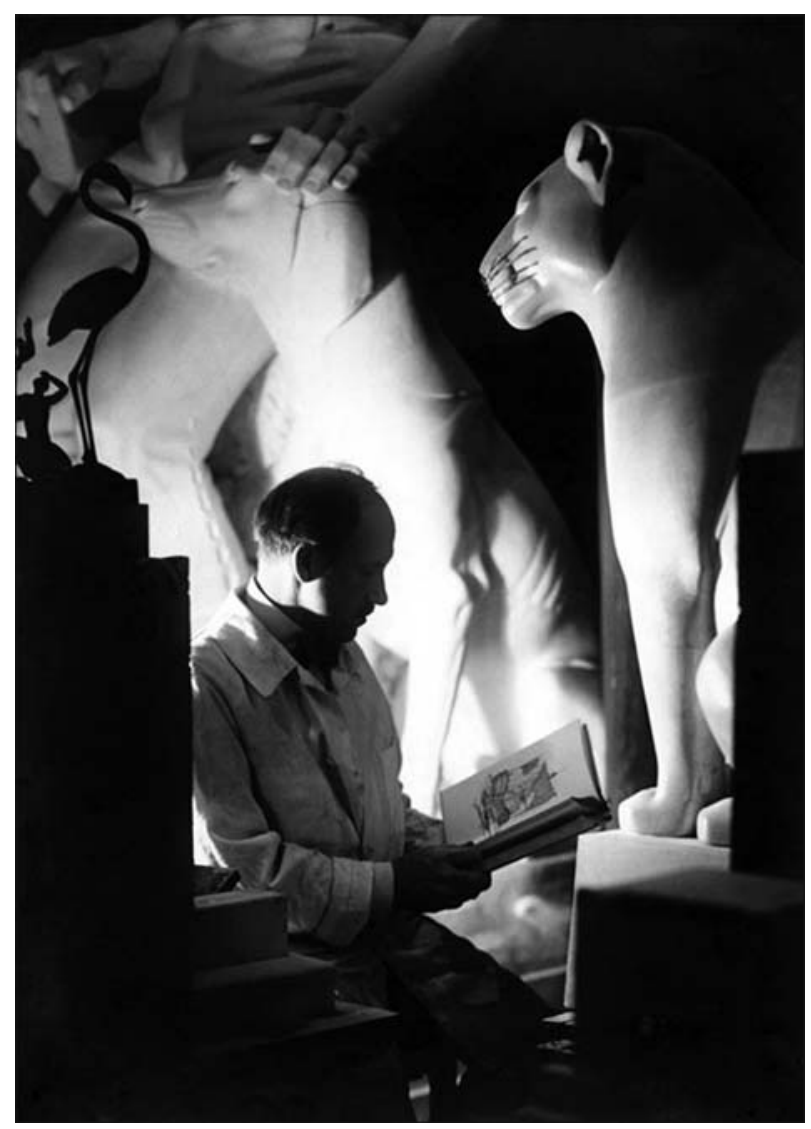

Manship 1939.
A los dieciocho años viajó a Nueva York para aprender junto con escultores experimentados (1). Uno de sus maestros lo animó para que se presentara a un concurso cuyo premio era una beca para viajar a Roma: lo ganó y marchó a Italia donde descubrió el arte griego, el romano y el egipcio. Las for-

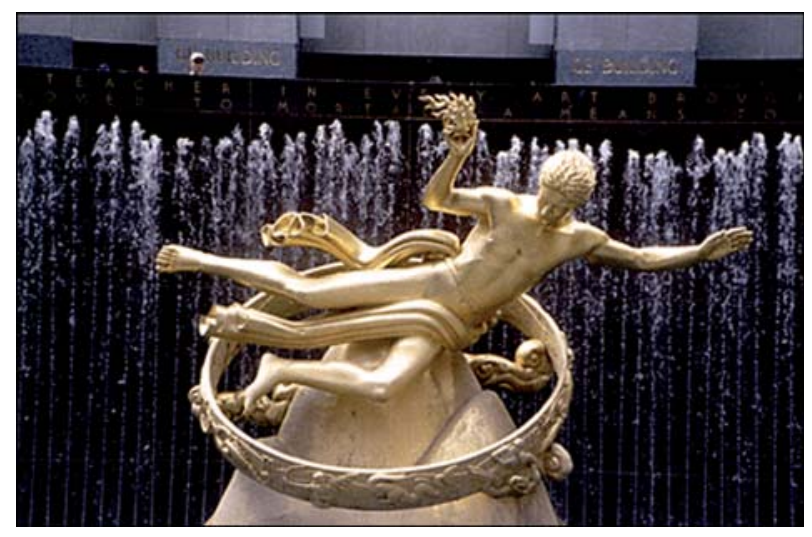

Prometeo (Rockefeller Center).

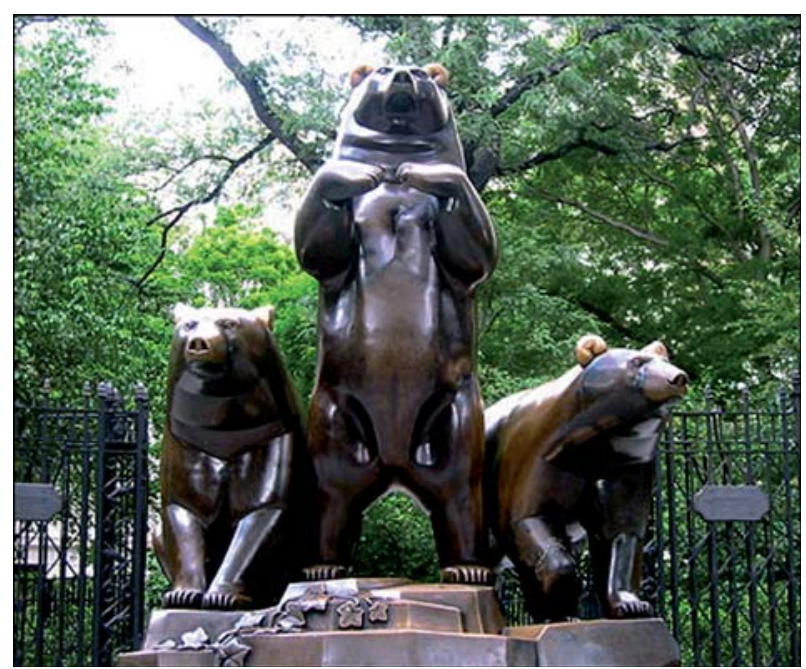

Grupo de osos.

\footnotetext{
1 Oftalmólogo.

E-mail: Fmir@mutuabalear.es
} 


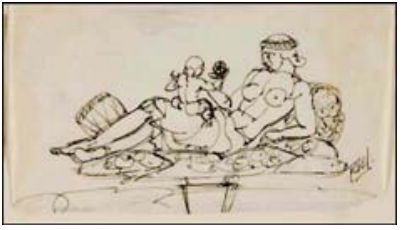

Boceto (Smithsonian).

mas simples y la decoración del arte clásico influyeron en el artista durante toda su vida (2).

Cuando regresó de Europa contrajo matrimonio con Isabel Mcllwaine con la que tuvo cuatro hijos, viviendo entre Nueva York y Europa donde conseguía importantes encargos a medida que su fama se internacionalizaba.

Todos sus bocetos, pinturas y dibujos son monocromáticos como corresponde a su anomalía.
Murió en 1966 a los ochenta y un años en su apartamento de Nueva York. Su obra escultórica se halla repartida en ambos continentes pero la colección más importante de sus dibujos y esculturas se encuentra en el Museo de Arte Americano de Minnesota (3).

\section{BIBLIOGRAFÍA}

1. Rather S. Archaism, Modernism and the Art of Paul Manship. Austin: University of Texas Press, 1993.

2. Paul Manship: changing taste in America. Saint Paul: Minnesota Museum of Art, 1985.

3. Paul Howard Manship, an intimate view: sculpture and drawings from the permanent collection of Minnesota Museum of Art. Saint Paul: Minnesota Museum of Art, 1972 